\title{
Characteristics, Properties and Analytical Methods of Paclitaxel: A Review
}

\author{
Renata Carolina Alves, Richard Perosa Fernandes, Josimar O. Eloy, Hérida \\ Regina Nunes Salgado \& Marlus Chorilli
}

To cite this article: Renata Carolina Alves, Richard Perosa Fernandes, Josimar O. Eloy, Hérida Regina Nunes Salgado \& Marlus Chorilli (2018) Characteristics, Properties and Analytical Methods of Paclitaxel: A Review, Critical Reviews in Analytical Chemistry, 48:2, 110-118, DOI: 10.1080/10408347.2017.1416283

To link to this article: https://doi.org/10.1080/10408347.2017.1416283

Accepted author version posted online: 14

Dec 2017.

Published online: 02 Feb 2018.

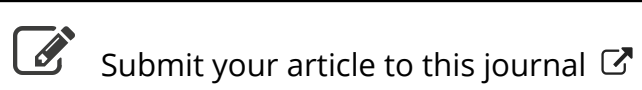

Џll Article views: 337

Citing articles: 2 View citing articles 


\title{
Characteristics, Properties and Analytical Methods of Paclitaxel: A Review
}

\author{
Renata Carolina Alves (iD) ${ }^{a}$, Richard Perosa Fernandes ${ }^{b}$, Josimar O. Eloy ${ }^{a}$, Hérida Regina Nunes Salgado (iD ${ }^{a}$, \\ and Marlus Chorilli (iD ${ }^{a}$

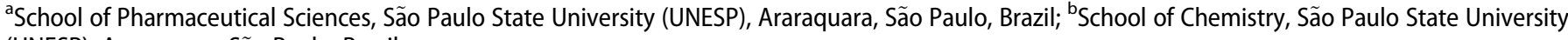 \\ (UNESP), Araraquara, São Paulo, Brazil
}

\begin{abstract}
Paclitaxel is a diterpenoid pseudoalkaloid, isolated from Taxus brevifolia, and is largely used as an antitumoral drug. The formulation of paclitaxel known as Taxol ${ }^{\circledR}$ employs a mixture of Cremophor EL and dehydrated ethanol, due the low drug water solubility. However, Taxol ${ }^{\circledR}$ causes some unwanted side effects due to the presence of Cremophor EL and ethanol in the formulation. Based on this, there is a need for the development of drug delivery systems to enhance the solubility, permeability and stability of paclitaxel and to promote a controlled and targeted delivery for better therapeutic effect and reduced side effects. In addition, the drug has been qualitatively and quantitatively analyzed in different delivery systems. In this context, several approaches were reported focusing on the optimization of analytical methods and development of new ones, considering the need of a fast, simple, with enough sensibility and selectivity assay, which can be a problem in some analysis. This review presents a summary of methods used in quantification of paclitaxel in different matrices, such as plasma, urine, plant extract, cells and delivery systems.
\end{abstract}

\section{KEYWORDS}

Analytical methods; drug delivery systems; paclitaxel; physicochemical properties

\section{Introduction}

Paclitaxel (PTX) is a diterpenoid pseudoalkaloid, composed by a taxane ring and an $\mathrm{N}$-benzoylphenylisoserine group, with molecular formula $\mathrm{C}_{47} \mathrm{H}_{51} \mathrm{NO}_{14}$, corresponding to molecular weight of $853 \mathrm{Da}$ and is a precursor drug of the class of taxanes, stabilizing agents of microtubules. ${ }^{[1]}$ This drug was first discovered from the bark of the Pacific yew Taxus brevifolia in 1963, showing promising results in preclinical studies against many tumors. This discovery was part of a National Cancer Institute program, which aims for the bioprospection of thousand plants looking for anticancer activity. ${ }^{[2]}$

In 1971, the drug was isolated from the yew tree extract and its chemical structure was elucidated by Dr Monre Wall of the "Research Triangle Institute" and Dr Mansukh Wani and collaborators. ${ }^{[3]}$ Its structure differed from all other taxanes essentially because it possesses a complex $\mathrm{C}-13$ side chain attached to the taxane ring, essential for its antitumor action (Figure 1). In 1979, an unique mechanism of reaction was identified, focusing the attention of the pharmaceutical field to paclitaxel, reviving the interests that was further stimulated when impressive activity was demonstrated in the National Cancer Institute tumor screening. ${ }^{[4]}$

Despite having a high anticancer activity, its development on an industrial scale was quite complicated. One of the problems encountered was related to its low solubility in water and to the fact that the drug was isolated in a very low yield from a low-growing and slow-growing tree. ${ }^{[5,6]}$ To solve the problem of the low solubility of PTX in water, in its formulation was added ethanol and polyethoxylated castor oil "Cremophor EL"
(1:1). This solution not only showed positive clinical results, but also revealed negative effects in the long term. The elevated levels of the surfactant Cremophor EL required for PTX administration cause undesirable side effects, such as hypersensitivity reactions. ${ }^{[7]}$

In 1992, PTX was approved by the Food and Drug Administration (FDA) for the treatment of ovarian and breast cancer, with good clinical results. ${ }^{[8,9]}$ There has been an increasing demand for this drug and is currently considered one of the most important anticancer drugs in the clinic for the treatment of ovarian, breast and lung cancer, as well as in the treatment of Kaposi's sarcoma (AIDS-related) in association with cisplatin. ${ }^{[10]}$

\section{Physical properties and pharmacokinetics}

Paclitaxel is a white to off-white crystalline powder. It is insoluble in water $\left(5.56 \times 10^{-3} \mathrm{~g} / \mathrm{L}\right)$, with fusion point near $216^{\circ} \mathrm{C}$ and is highly lipophilic. Its plasma clearance is found to be biphasic. ${ }^{[11]}$ The first rapid decline is consequence of the distribution to the central compartment and elimination of the drug and the later phase is due, in part, to the efflux of the drug from the peripheral compartment. ${ }^{[12]}$

The usually accepted dose is $200-250 \mathrm{mg} / \mathrm{m}^{2}$ and is given as 3- and 24-hour infusion and the pharmacokinetics of this drug shows high standard deviation. Terminal half-life was found to be in the range of 1.3-8.6 hours (mean 5 hours) and the steady-state volume of distribution was found to be $\sim 87.1 \mathrm{~mL} / \mathrm{min} / \mathrm{m}^{2 .[13]}$ 


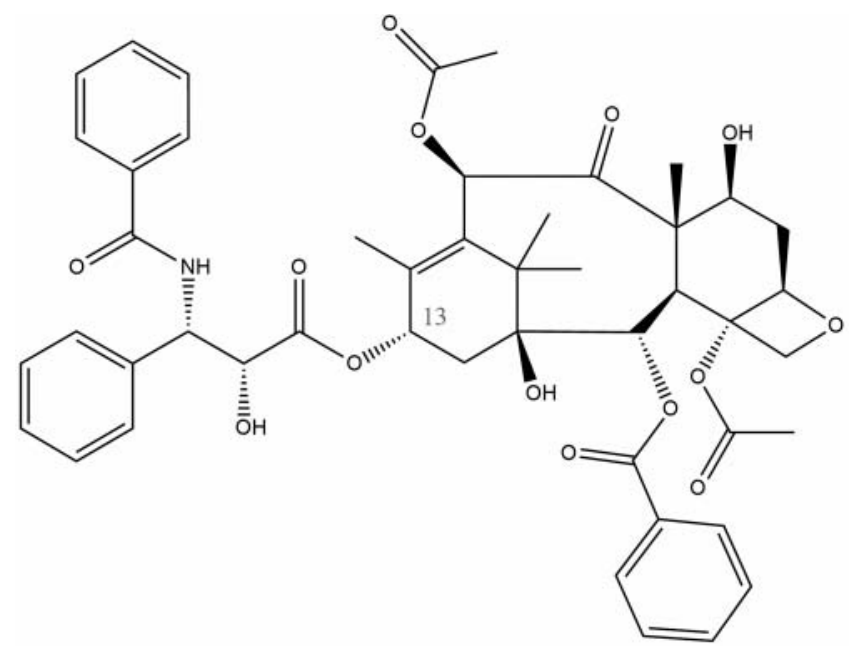

Figure 1. Structure of paclitaxel.

The drug suffers an extensive P-450 (isoenzyme CYP3A and CYP2C) mediated hepatic metabolism and less than $10 \%$ drug in the unchanged form is excreted in the urine. ${ }^{[14]}$ Most of the drug is excreted in the feces and more than $90 \%$ of the PTX binds rapidly and extensively to plasma proteins. ${ }^{[1,15]}$ In rats, the highest concentration of the drug was found in the lung, liver, kidney and spleen and was basically excluded from the brain and testes after an infusion of 6 hours. ${ }^{[13]}$

\section{Mechanisms of action}

PTX has a mechanism of action that differs from most cytotoxic agents. This drug does not interact directly with nuclear components (DNA and RNA), unlike some other chemotherapeutic drugs. ${ }^{[16]}$ The main site of action paclitaxel is the microtubules, however, unlike the vinca alkaloids or colchicine derivatives, which induce depolymerization of the microtubules, paclitaxel acts during the mitotic phase of cell division and promotes the polymerization of the tubulin proteins and their assembly, resulting in the stabilization of microtubules and block the cell cycle, with consequent cell death. ${ }^{[17]}$

Microtubules are one of the major components of the cytoskeleton of eukaryotic cells where they play several important cellular functions. ${ }^{[18]}$ They are fundamental in the development and maintenance of cell shape, in the transport of vesicles, mitochondria and other components in the intracellular environment, cell signaling and mitotic spindle formation during cell division. ${ }^{[19-21]}$

Structurally, the microtubules are made up of 13 longitudinally aligned tube-shaped tubes. Each linear protofilament consists of several heterodimers of alpha and beta tubulin. ${ }^{[21-23]}$ The microtubules consist of a positive $(+)$ end terminating with a beta tubulin and a negative (-) terminus ending with an alpha tubulin subunit. ${ }^{[10]}$ One of the characteristic features of microtubules is their ability to shorten and lengthen in a stochastic fashion through loss or addition of $\alpha / \beta$-tubulin heterodimers from microtubule ends, a phenomenon referred to as "dynamic instability."

Dynamic instability is mediated by the exchange of guanosine triphosphate (GTP)/guanosine diphosphate (GDP), therefore the $\alpha$-subunit of tubulin binds irreversibly to GTP reaching the appropriate configuration for microtubule polymerization, while the $\beta$-subunit of tubulin establishes a reversible binding with GTP or GDP, leading respectively to polymerization or depolymerization of the microtubule. The two ends of each microtubule have very different dynamic characteristics. The positive end shows more dynamism than the negative end. Because of these differences, the microtubules of mitotic spindle are constantly polymerizing at the positive ends and depolymerizing at the negative ends. ${ }^{[24]}$

This regulation of the microtubules affected by the cells involves several endogenous cellular proteins and is a fundamental requirement for the various cellular activities to occur. The microtubules dynamics are higher in the mitotic phase and it is at this stage that the stress and formation of the kinetochore are substantial for a correct fixation, separation and segregation of chromosomes. The dynamic capacity of microtubules depends, among other factors, on the different isotypes of $\alpha$ and $\beta$ tubulin and on the interaction with proteins that interact with microtubules, the microtubule-associated proteins (MAPs). There are MAPs capable of stabilizing the microtubules (MAP4 and Tau) and MAPs with destabilizing action of the microtubules (proteins of the stathmin family). ${ }^{[24]}$

Taxanes and other Microtubule-Stabilizing Agents (MSA) can bind to the $\beta$-subunit of tubulin in the lumen of the polymerized microtubules, causing microtubular dynamic suppression and stabilization thereof. Thus, mitosis ends up being interrupted by cell accumulation in the G2/M phase of the cell cycle, which, in turn, prevents cell division and consequent proliferation of neoplastic cells. ${ }^{[25]}$ The effect of MSA on microtubules not only affects the progression of the cell cycle, but also causes changes in signaling pathways, such as apoptosis.

Despite these highly visible morphological changes, the mechanism of cell death is not completely known. Cell death depends on drug concentrations and the time of cell exposure. Additionally, it has been found that PTX can cause cell death independently of the occurrence of mitosis. It can bind to the Bcl-2 protein, which regulates apoptosis and induces phosphorylation and through a complex process that leads to cell death. However, the tendency of PTX to bind to this protein is less than to bind to tubulin. ${ }^{[26]}$

\section{Drug delivery systems}

Several delivery systems can be employed for PTX loading, such as liposomes, polymeric nanoparticles, micelles, dendrimers, inorganic nanoparticles, carbon nanotubes, hydrogels and cyclodextrin nanoparticles. ${ }^{[2]}$ Based on this, nanocarriers have attracted increasing attention in recent years, especially for cancer therapies due to several advantages over the standard therapy.

Among the advantages of nanocarriers for PTX delivery, the most important are the following: nanoparticles can improve the solubility of this drug, they are small, facilitating delivery of the drug to the tumor because of permeability and retention (EPR) effect and they can escape the recognition of reticuloendothelial system (RES) because of steric hindrance caused by PEGylation, which reduces the side effects of the drug consequently improving the pharmacokinetic profiles of the drug from nanocarriers. ${ }^{[27,28]}$ 
Yang and collaborators ${ }^{[29]}$ developed a PEGylated liposomal of paclitaxel with the purpose of improving the solubility of PTX as well as the physicochemical stability of liposome in comparison to the current $\mathrm{Taxol}^{\circledR}$ formulation. The results showed the PEGylated liposomes increased the biological halftime of PTX and decreased the uptake in the liver, spleen and lung while increasing the uptake in tumor tissues after injection compared to Taxol ${ }^{\circledR}$.

Jin et al. ${ }^{[30]}$ prepared PLGA nanoparticles with PTX encapsulated and determined cytotoxicity in two hypoxic human tumor cell lines, namely, breast carcinoma (MCF-7) and carcinoma cervices (HeLa). Based on the results obtained, the authors concluded that PTX-loaded PLGA nanoparticles may be considered a potential drug delivery system to eradicate hypoxic tumor cells, once this formulation retained its bioactivity to block cells in $\mathrm{G} 2 / \mathrm{M}$ phase and exhibited cytotoxic effect on both cell lines and its cytotoxicity was more significant than free PTX.

Besides that, the surface of nanocarriers systems can be functionalized with active ligands, such as monoclonal antibodies, transferrin, folate, peptide or aptamers for targeting purpose, which, in turn, will further increase the tumor uptake and decrease the side effects of the drug. ${ }^{[27,28]}$

For this purpose, Eloy and coworkers ${ }^{[31]}$ developed functionalized liposomes with antibodies (Trastuzumab) containing PTX and rapamycin (RAP). The results of this study revealed that the immunolipossomes better controlled the tumor growth owing to higher cell uptake when compared to the control groups. Therefore, breast cancer-targeted immunoliposomes have potential for further clinical evaluation.

Teow et al. ${ }^{[32]}$ investigated the ability of a third-generation (G3) polyamidoamine (PAMAM) dendrimer-based carrier to enhance the permeability of PTX and to overcome cellular barriers. The surface of dendrimers was modified with lauryl chains and conjugated with PTX via a glutaric anhydride linker. The authors suggested that G3 and surface-modified G3 PAMAM dendrimers can act as potential nanocarriers to enhance the permeability of poorly water-soluble drugs (e.g. paclitaxel) that are P-gp efflux transporter substrates. Thus, the dendrimer-based prodrug might be of great interest for the development of delivery systems containing PTX to overcome challenging biological barriers.

Emami et al. ${ }^{[33]}$ developed a receptor-targeted micelle based on tocopherol succinate-chitosan-polyethylene glycolfolic acid (TS-CS-PEG-FA) and loaded with paclitaxel. They observed that the folate on the surface of the micelles significantly increased the cytotoxic effect of PTX due to folate receptor-mediated endocytosis. Furthermore, the tissue distribution studies revealed the PTX/TS-CS-PEG-FA micelles displayed prolonged residence time in blood circulation and increased accumulation of the drug in tumor tissue.

Sahoo and collaborators ${ }^{[34]}$ conjugated transferrin into a nanoparticle paclitaxel loaded to assay the efficacy in prostate cancer. The authors demonstrated that the encapsulation of PTX in the nanoparticles reduced tumor growth, and the use of transferrin enhanced the cellular uptake of the nanoparticles, evidencing that the transferrin conjugation is mediated by the transferrin receptors.

American BioScience, Inc., Santa Monica, California developed a new commercially available formulation where paclitaxel is bound to albumin nanoparticles with particle size of $130 \mathrm{~nm}$. This formulation uses the natural properties of albumin to reversibly bind paclitaxel, transporting it across the endothelial cell and concentrate it in areas of tumor. The advantages of Abraxane $^{\circledR}$ are the use of albumin as a vehicle to eliminate the solvent-related toxicities and consequently eliminates the need for steroid and antihistamine premedication, besides that, this formulation does not use Cremophor in the suspension, reducing toxicity and thus the infusion duration. ${ }^{[35,36]}$

\section{Analytical methods}

The advances in research related to the development and improvement of certain drugs have led to a growing interest in the analytical field that addresses methodologies that aim to quantify and identify molecules in different matrices. Furthermore, the need to optimize or create methods focusing on better analytical signal of interest, lower consumption of reagents and solvents or shorter analytical times are important factors that should be taken into consideration. Altogether, an optimized analytical method demands lower use of resources and avoids laborious procedures, as an attempt to avoid analytical errors and consequently problems in validation of methodologies. ${ }^{[37,38]}$

Several analytical methods have been described in the literature for the quantification of PTX in different matrices. These methods include, for instance, immunoassays, micellar electrokinetic chromatography (MEKC), tubulin-based biochemical and chromatography-based assays, described in the next topics. Most of techniques involve the use of high-performance liquid chromatography (HPLC) coupled with UV or MS detector, possibly due to the higher sensibility and resolution, as well as the ability to work with matrices of different types, assisting in analyzes where there may be possible effects of matrices and interference. In addition, the HPLC technique is used as a standard in the pharmaceutical industry and is recognized as a standard method in American pharmacopeia. ${ }^{[39]}$

In the immunoassays method, that is reported for quantification in biological samples, ${ }^{[40-44]}$ the process consists of one reaction that binds paclitaxel to an antibody followed by incubation to form an immune complex. This complex is separated from the unbound reagent by physical or chemical separation technique and the analysis involve measuring the label activity (e.g. radiation, fluorescence or enzyme) in either the bound or free fraction. ${ }^{[4]}$ For PTX, this methodology expresses very slow developments in the past decades, which could be attributed to the excessive pre-treatment, which is laborious and time consuming, despite having similar sensibility and selectivity compared to LC-MS/MS.

Tubulin-based biochemical assay, a separation-free homogeneous method, offers low analysis time and minimal sample pretreatment, but the sensitivity is limited compared to HPLCUV or HPLC-MS. ${ }^{[43,46]}$ The technique was explored for quantification of paclitaxel by Hamel et al., who measured hydrolysis of labeled GTP to GDP, since GDP formation is concentration dependent of paclitaxel and it is possible to find a linear relationship between them. ${ }^{[43}$. In a second approach, Morais et al. measured paclitaxel by the change in fluorescence polarization response by the binding of paclitaxel to tubulin rhodamine, 


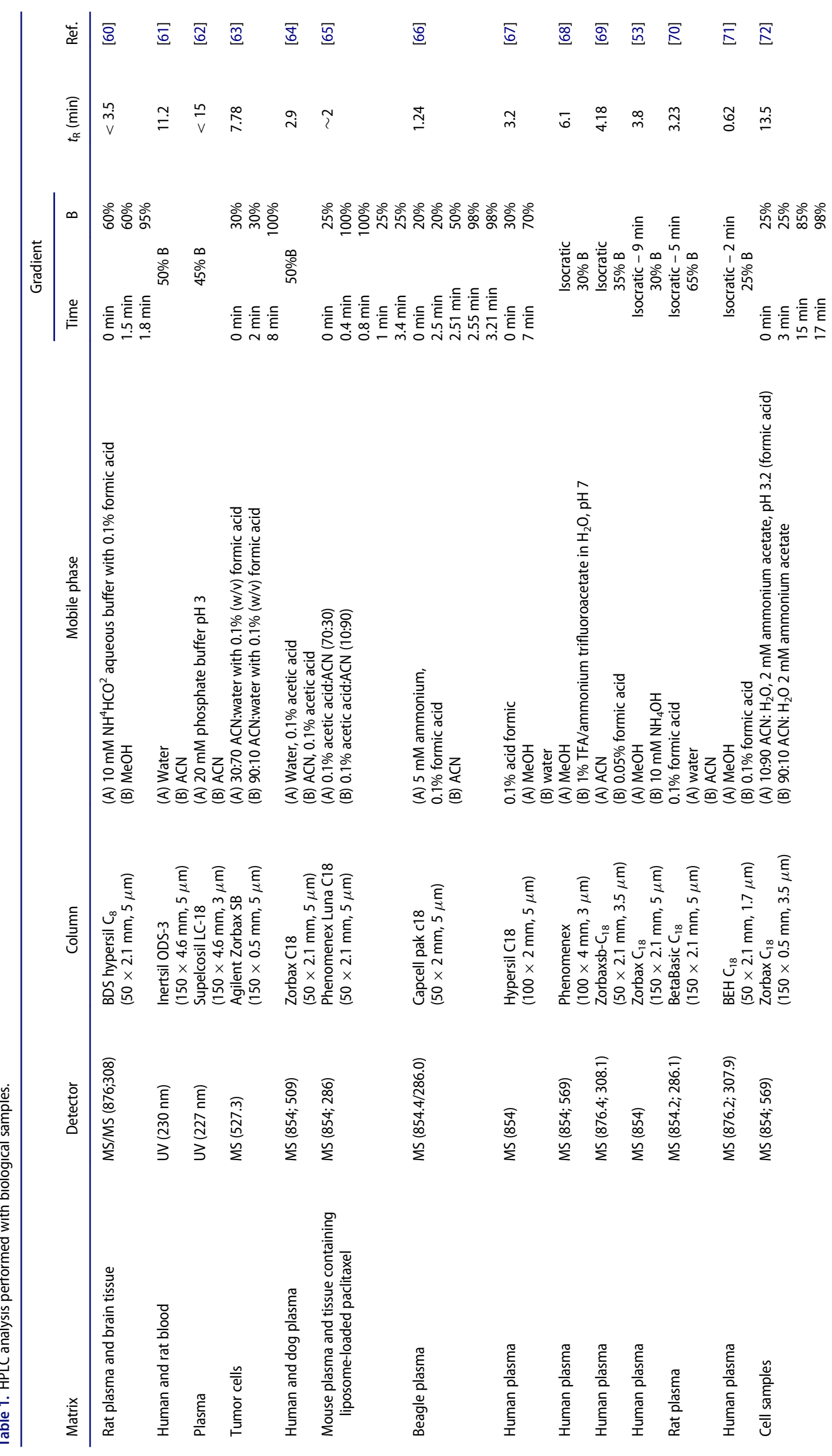




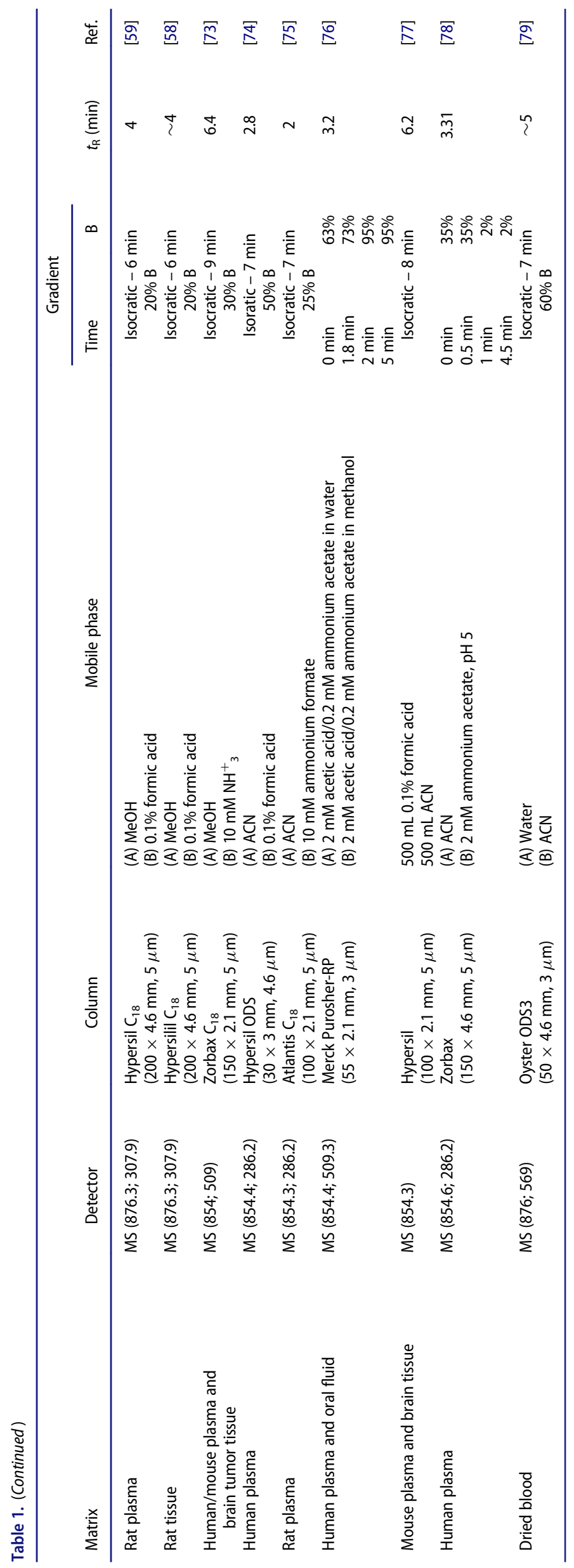


finding a linear response concentration range of 25.6-299 ng/ mL of PTX. ${ }^{[46]}$

Micellar electrokinetic chromatography (MEKC) was used to quantify PTX in human plasma, serum, plant extract and urine. ${ }^{[4-50]}$ The technique consists of a separation method in which micelles act as a pseudo stationary phase in a solution, usually coupled with UV detector for the signal response. MEKC requires smaller sample volume, consequently having higher LLOQ (lower limit of quantification) than obtained by most HPLC-UV analysis ${ }^{[51]}$; however, this technique requires less solvent waste and shows good result if the matrix have taxines, which is a toxic alkaloid compound isolated from taxus spp., avoiding coeluting problems that exist in HPLC. ${ }^{[49]}$

Comparative study of first-derivative spectrophotometry with ultraviolet detection (DS-UV) and HPLC methods for quantification of paclitaxel in liposomal formulation was proposed as an alternative method by Barbosa et al. for routine use. The DS-UV method was developed within the range of
200-400 $\mathrm{nm}$ with a $2-\mathrm{nm}$ bandwidth, measurements were performed using the zero-crossing wavelengths in the first derivative of the absorbance spectra, measuring the amplitude at $246 \mathrm{~nm}$. No significant difference was found between this approach and HPLC-UV results in the validation study. DS-UV provided and alternative method that is fast, simple and with low cost compared to HPLC-UV. ${ }^{[52]}$

The analytical methods found in the literature for PTX quantification employing liquid chromatography(LC) usually employ reversed-phase C8 or C18 silica bounded columns. ${ }^{[53]}$ The mobile phase generally consists of $50 \%$ or more organic solvents $(\mathrm{v} / \mathrm{v})$, with methanol $(\mathrm{MeOH})$ or acetonitrile $(\mathrm{ACN})$, which can be related with the stability of paclitaxel in nonaqueous solvents, since the compound can suffer degradation or epimerization in aqueous solution. ${ }^{[54-56]}$ Moreover, the increase of eluent strength using organic solvents can lead to shorter LC analysis time. ${ }^{[57]}$ Additives, such as buffer, acids or bases, are commonly used with the purpose of improving

Table 2. HPLC analysis performed with diverse matrices.

\begin{tabular}{|c|c|c|c|c|c|c|c|}
\hline \multirow[b]{2}{*}{ Matrix } & \multirow[b]{2}{*}{ Detector } & \multirow[b]{2}{*}{ Column } & \multirow[b]{2}{*}{ Mobile phase } & \multicolumn{2}{|c|}{ Gradient } & \multirow[b]{2}{*}{$t_{\mathrm{R}}(\min )$} & \multirow[b]{2}{*}{ Ref } \\
\hline & & & & Time & B & & \\
\hline Plant extract & MS $(854.4 ; 286.1)$ & $\begin{array}{l}\text { Eclipse XDB-C18 } \\
(150 \times 4.6 \mathrm{~mm}, 5 \mu \mathrm{m})\end{array}$ & $\begin{array}{l}\text { (A) Water } \\
\text { (B) ACN }\end{array}$ & \multicolumn{2}{|c|}{$\begin{array}{c}\text { Isocratic }-36 \text { min } \\
60 \% \text { B }\end{array}$} & 31.56 & {$[80]$} \\
\hline Bulk drug and injectable dosage form & UV (200-400 nm) & $\begin{array}{l}\text { Whatman TAC- } 1 \\
(250 \times 4.6 \mathrm{~mm}, 5 \mu \mathrm{m})\end{array}$ & $\begin{array}{l}\text { (A) Water } \\
\text { (B) ACN }\end{array}$ & \multicolumn{2}{|c|}{$\begin{array}{c}\text { (A) Isocratic - } 12 \mathrm{~min} \\
38 \% \text { B } \\
\text { (B) Gradient } \\
4 \% / \mathrm{min}\end{array}$} & 17 & [81] \\
\hline Plant extract, body fluid and tissues & MS (854.2; 286.1) & $\begin{array}{l}\text { Kinetex } \mathrm{C}_{18} \\
(100 \times 2.6 \mathrm{~mm}, 5 \mu \mathrm{m})\end{array}$ & $\begin{array}{l}\text { (A) } 0.1 \% \mathrm{HAc}, \mathrm{NH}_{4} \mathrm{Ac}: \mathrm{MeOH} 90: 10 \\
\text { (B) } \mathrm{MeOH}\end{array}$ & $\begin{array}{c}0 \mathrm{~min} \\
1 \mathrm{~min} \\
6 \mathrm{~min} \\
11 \mathrm{~min} \\
13 \mathrm{~min}\end{array}$ & $\begin{array}{r}5 \% \\
40 \% \\
65 \% \\
95 \% \\
95 \%\end{array}$ & - & {$[82]$} \\
\hline Copaiba essential oil extract & UV (228 nm) & $\begin{array}{l}\text { Uptisphere C-18 } \\
(150 \times 3 \mathrm{~mm}, 3 \mu \mathrm{m})\end{array}$ & $\begin{array}{l}\text { (A) Water } \\
\text { (B) ACN }\end{array}$ & \multicolumn{2}{|c|}{$\begin{array}{c}\text { Isocratic }-15 \text { min } \\
50 \% \text { B }\end{array}$} & $\sim 9.7$ & [83] \\
\hline Plant extract & UV (227 nm) & $\begin{array}{l}\text { Eclipse XDB-C } 18 \\
(250 \times 4.6 \mathrm{~mm}, 5 \mu \mathrm{m})\end{array}$ & $\begin{array}{l}\text { (A) } 10 \mathrm{mM} \mathrm{NH}_{4} \mathrm{AC} \\
\text { (B) ACN }\end{array}$ & $\begin{array}{c}0 \mathrm{~min} \\
3 \mathrm{~min} \\
35 \mathrm{~min} \\
45 \mathrm{~min} \\
50 \mathrm{~min}\end{array}$ & $\begin{array}{c}10 \% \\
10 \% \\
80 \% \\
95 \% \\
95 \%\end{array}$ & - & [84] \\
\hline Polymer & UV (227 nm) & $\begin{array}{l}\text { Inertsil ODS-3V } \\
(250 \times 4.6 \mathrm{~mm}, 5 \mu \mathrm{m})\end{array}$ & $\begin{array}{l}\text { (A) Water } \\
\text { (B) ACN }\end{array}$ & $\begin{array}{l}0 \mathrm{~min} \\
15 \mathrm{~min} \\
23 \mathrm{~min}\end{array}$ & $\begin{array}{r}50 \% \\
100 \% \\
100 \%\end{array}$ & 10.5 & [85] \\
\hline Formulations containing Cremophor EL & UV (227 nm; 360 nm) & $\begin{array}{l}\text { Supelcosil LC-F } \\
\left(5 \mu \mathrm{m}, 250 \times 4.6 \mathrm{~mm}^{2}\right)\end{array}$ & $\begin{array}{l}\text { (A) Water } \\
\text { (B) ACN }\end{array}$ & $\begin{array}{l}20 \mathrm{~min} \\
60 \mathrm{~min} \\
70 \mathrm{~min}\end{array}$ & $\begin{array}{l}70 \% \\
60 \% \\
60 \%\end{array}$ & 37.28 & [86] \\
\hline Keratin & MS (853.9) & $\begin{array}{l}\text { Symmetry } C_{18} \\
(100 \times 2.1 \mathrm{~mm}, 5 \mu \mathrm{m})\end{array}$ & $\begin{array}{l}\text { (A) } A C N \\
\text { (B) water, } 0.1 \% \text { formic acid }\end{array}$ & $\begin{array}{l}12 \mathrm{~min} \\
15 \mathrm{~min} \\
19 \mathrm{~min}\end{array}$ & $\begin{array}{r}45 \% \\
100 \% \\
100 \%\end{array}$ & 9.1 & [87] \\
\hline Co-loaded paclitaxel liposome & UV (227 nm) & Lichrospher $\mathrm{C}_{18}$ & $\begin{array}{l}\text { (A) Water } \\
\text { (B) ACN }\end{array}$ & & $\%$ B & - & [88] \\
\hline Paclitaxel in liposomal formulation & UV (227 nm) & $\begin{array}{l}\text { Lichrospher 100RP-18 } \\
(250 \times 4 \mathrm{~mm}, 5 \mu \mathrm{m})\end{array}$ & $\begin{array}{l}\text { (A) Water } \\
\text { (B) ACN }\end{array}$ & & $\%$ B & $\sim 6$ & [52] \\
\hline Paclitaxel-loaded PEGylated immunolipossome & UV $(227 \mathrm{~nm})$ & $\begin{array}{l}\text { LiChrospher } 100 \mathrm{RP}-18 \\
(250 \times 4.6 \mathrm{~mm}, 5 \mu \mathrm{m})\end{array}$ & $\begin{array}{l}\text { (A) Water } \\
\text { (B) ACN }\end{array}$ & & $\%$ B & - & [89] \\
\hline Paclitaxel-dendrimer conjugate & UV $(230 \mathrm{~nm})$ & $\begin{array}{l}\text { Phenomenex } C_{18} \\
(250 \times 4.6 \mathrm{~mm}, 5 \mu \mathrm{m})\end{array}$ & $\begin{array}{l}\text { (A) } \mathrm{MeOH} \\
\text { (B) } 0.05 \% \mathrm{w} / \mathrm{v} \text { TFA }\end{array}$ & & $\%$ B & - & [32] \\
\hline Polymeric micelle & UV (227 nm) & $\begin{array}{l}\text { Bondapak- } C_{18} \\
(250 \times 3.9 \mathrm{~mm}, 5 \mu \mathrm{m})\end{array}$ & $\begin{array}{l}\text { (A) } 0.01 \mathrm{M} \mathrm{KH}_{2} \mathrm{PO}_{4} \\
\text { (B) ACN, pH } 3.5\end{array}$ & & $\%$ B & - & [33] \\
\hline Paclitaxel-loaded PLGA nanoparticles & UV $(227 \mathrm{~nm})$ & $\begin{array}{l}\text { Sunfire Water } \\
(250 \times 4.6 \mathrm{~mm}, 5 \mu \mathrm{m})\end{array}$ & $\begin{array}{l}\text { (A) Water } \\
\text { (B) ACN }\end{array}$ & & $\%$ B & - & {$[90]$} \\
\hline PEGylated liposomal paclitaxel & UV(227 nm) & $\begin{array}{l}\text { LiChrosphere RP-18 } \\
(250 \times 4.6 \mathrm{~mm}, 5 \mu \mathrm{m})\end{array}$ & $\begin{array}{l}\text { (A) Water } \\
\text { (B) ACN }\end{array}$ & & $\%$ B & & [29] \\
\hline PEGylated-loaded nanoparticles & UV(228 nm) & $\begin{array}{l}\text { Phenomenex } \\
(250 \times 4.6 \mathrm{~mm}, 5 \mu \mathrm{m})\end{array}$ & $\begin{array}{l}\text { (A) Ammonium acetate } 10 \mathrm{~mm} \\
\text { (B) ACN }\end{array}$ & & $\%$ B & - & [34] \\
\hline
\end{tabular}


selectivity, separation, better peak shape or to improve the observed signal. Tables 1 and 2 summarize some of the methods found in the literature regarding the type of matrix, detector, column, mobile phase and retention time. Regarding the common detectors in LC, for UV, absorbance is generally measured at $227 \mathrm{~nm}$, a wavelength in which the maximum absorption occurs from its baccatin III ring structure, representative of the taxanes structure. ${ }^{[7]}$ In MS, the ESI ionization was compared and it appears that ionization in positive mode results in an optimal analytical response, ${ }^{[58,59]}$ since paclitaxel has more hydrogen acceptors than donors, ${ }^{[57]}$ besides that positive mode can result in better intensity.

\section{Conclusion}

A great number of analytical methods have been reported in the literature for quantification of paclitaxel in a wide diversity of matrices, including delivery systems and biological matrices. Among these methods, immunoassays show good sensibility and selectivity, like LC-MS/MS, but the time consumed in the pre-treatment limits their application. Tubulin-based biochemical assay overcomes this problem, but has low sensibility compared to HPLC-UV or HPLC-MS, whereas MECK presents the possibility to quantify PTX in presence of taxines, but has lower LLOQ than most HPLC-UV methods and DS-UV, which can be very useful in routine analysis. Most of methods report the use of HPLC with UV or MS detectors, mostly because these techniques can fulfill the requisites of sensitivity and selectivity needed in most analysis, but even in these methods, the methods need to be optimized due to the possibility of matrix effect and the due to the amount of recourses available.

\section{ORCID}

Renata Carolina Alves iD http://orcid.org/0000-0002-2901-8779 Hérida Regina Nunes Salgado (D) http://orcid.org/0000-0002-0385-340X Marlus Chorilli iD http://orcid.org/0000-0002-6698-0545

\section{References}

[1] Rowinsky, E. K.; Cazenave, L. A.; Donehower, R. C. Taxol: A Novel Investigational Antimicrotubule Agent. J. Natl. Cancer Inst. 1990, 82 (15), 1247-1259. DOI: 10.1093/jnci/82.15.1247.

[2] Rowinsky, E. K.; Donehower, R. C. Paclitaxel (Taxol). N. Engl. J. Med. 1995, 332 (15), 1004-1014. DOI: 10.1056/NEJM199504133321507.

[3] Wani, M. C.; Taylor, H. L.; Wall, M. E.; Coggon, P.; Mcphail, A. T. Plant Antitumor Agents VI. The Isolation and Structure of Taxol, A Novel Antileukemic and Antitumor Agent from Taxus brevifolia2. J. Am. Chem. Soc. 1971, 93 (9), 2325-2327. DOI: 10.1021/ja00738a045.

[4] Schiff, P. B.; Fant, J.; Horwitz, S. B. Promotion of Microtubule Assembly In Vitro by Taxol. Nature 1979, 277 (5698), 665-667. DOI: $10.1038 / 277665 \mathrm{a} 0$.

[5] Jennewein, S.; Croteau, R. Taxol: Biosynthesis, Molecular Genetics, and Biotechnological Applications. Appl. Microbiol. Biotechnol. 2001, 57 (1-2), 13-19. DOI: 10.1007/s002530100757.

[6] Singla, A. K.; Garg, A.; Aggarwal, D. Paclitaxel and Its Formulations. Int. J. Pharm. 2002, 235 (1-2), 179-192. DOI: 10.1016/S0378-5173 (01)00986-3.

[7] Kingston, D. G. I. The Shape of Things to Come: Structural and Synthetic Studies of Taxol and Related Compounds. Phytochemistry 2007, 68 (14), 1844-1854. DOI: 10.1016/j.phytochem. 2006.11 .009 .
[8] McGuire, W. P. Taxol: A Unique Antineoplastic Agent with Significant Activity in Advanced Ovarian Epithelial Neoplasms. Ann. Intern. Med. 1989, 111 (4), 273. DOI: 10.7326/0003-4819-111-4-273.

[9] O'Shaughnessy, J. A.; Cowan, K. H. Current Status of Paclitaxel in the Treatment of Breast Cancer. Breast Cancer Res. Treat. 1995, 33 (1), 27-37. PMID: 7749130.

[10] Altmann, K.-H.; Gertsch, J. Anticancer Drugs from Nature-Natural Products as a Unique Source of New Microtubule-Stabilizing Agents. Nat. Prod. Rep. 2007, 24 (2), 327-357. DOI: 10.1039/B515619J.

[11] Weiss, R. B.; Donehower, R. C.; Wiernik, P. H.; Ohnuma, T.; Gralla, R. J.; Trump, D. L.; Baker, J. R.; Van Echo, D.; Von Hoff, D. D.; Leyland-Jones, B. Hypersensitivity Reactions from Taxol. J. Clin. Oncol. 1990, 8 (7), 1263-1268. DOI: 10.1093/jnci/85.24.2036.

[12] Brown, T.; Havlin, K.; Weiss, G.; Cagnola, J.; Koeller, J.; Kuhn, J.; Rizzo, J.; Craig, J.; Phillips, J.; Von Hoff, D. A Phase I Trial of Taxol Given by a 6-Hour Intravenous Infusion. J. Clin. Oncol. 1991, 9 (7), 1261-1267. DOI: 10.1200/JCO.1991.9.7.1261.

[13] Rowinsky, E. K.; Donehower, R. C. The Clinical Pharmacology of Paclitaxel (Taxol). Semin. Oncol. 1993, 20 (4 Suppl 3), 16-25. PMID: 8102014.

[14] Rizzo, J.; Riley, C.; von Hoff, D.; Kuhn, J.; Phillips, J.; Brown, T. Analysis of Anticancer Drugs in Biological Fluids: Determination of Taxol with Application to Clinical Pharmacokinetics. J. Pharm. Biomed. Anal. 1990, 8 (2), 159-164. DOI: 10.1016/0731-7085(90)80023-I.

[15] Wiernik, P. H.; Schwartz, E. L.; Einzig, A.; Strauman, J. J.; Lipton, R. B.; Dutcher, J. P. Phase I Trial of Taxol Given as a 24-hour Infusion Every 21 days: Responses Observed in Metastatic Melanoma. J. Clin. Oncol. 1987, 5 (8), 1232-1239. DOI: 10.1200/JCO.1987.5.8.1232.

[16] Surapaneni, M. S.; Das, S. K.; Das, N. G. Designing Paclitaxel Drug Delivery Systems Aimed at Improved Patient Outcomes: Current Status and Challenges. ISRN Pharmacol. 2012, 2012, 1-15. DOI: $10.5402 / 2012 / 623139$.

[17] Dumontet, C.; Sikic, B. I. Mechanisms of Action of and Resistance to Antitubulin Agents: Microtubule Dynamics, Drug Transport, and Cell Death. J. Clin. Oncol. 1999, 17 (3), 1061. DOI: 10.1200/ JCO.1999.17.3.1061.

[18] Magnani, M.; MacCari, G.; Andreu, J. M.; Díaz, J. F.; Botta, M. Possible Binding Site for Paclitaxel at Microtubule Pores. FEBS J. 2009, 276 (10), 2701-2712. DOI: 10.1111/j.1742-4658.2009.06994.x.

[19] Mollinedo, F.; Gajate, C. Microtubules, Microtubule-Interfering Agents and Apoptosis. Apoptosis 2003, 8 (5), 413-450. DOI: 10.1023/A:1025513106330.

[20] Jordan, M. A.; Wilson, L. Microtubules as a Target for Anticancer Drugs. Nat. Rev. Cancer 2004, 4 (4), 253-265. DOI: 10.1038/nr1317.

[21] Marchetti, P.; Urien, S.; Cappellini, G. A.; Ronzino, G.; Ficorella, C. Weekly Administration of Paclitaxel: Theoretical and Clinical Basis. Crit. Rev. Oncol. Hematol. 2002, 44 Suppl, S3-13. DOI: 10.1016/ S1040-8428(02)00109-9.

[22] Morris, P. G.; Fornier, M. N. Microtubule Active Agents: Beyond the Taxane Frontier. Clin. Cancer Res. 2008, 14 (22), 7167-7172. DOI: 10.1158/1078-0432.CCR-08-0169.

[23] Desai, A.; Mitchison, T. J. Microtubule Polymerization Dynamics. Annu. Rev. Cell Dev. Biol. 1997, 13 (1), 83-117. DOI: 10.1146/ annurev.cellbio.13.1.83.

[24] Pasquier, E.; Kavallaris, M. Microtubules: A Dynamic Target in Cancer Therapy. IUBMB Life 2008, 60 (3), 165-170. DOI: 10.1002/ iub.25.

[25] Gligorov, J. Preclinical Pharmacology of the Taxanes: Implications of the Differences. Oncologist 2004, 9 (suppl_2), 3-8. DOI: 10.1634/ theoncologist.9-suppl_2-3.

[26] Haldar, S.; Chintapalli, J.; Croce, C. M. Taxol Induces bcl-2 Phosphorylation and Death of Prostate Cancer Cells Taxol Induces bcl-2 Phosphorylation and Death of Prostate Cancer Cells. Cancer Res. 1996, 56, 1253-1255. PMID: 8640809.

[27] Ma, P. Paclitaxel Nano-Delivery Systems: A Comprehensive Review. J. Nanomed. Nanotechnol. 2013, 4 (2), 1-35. DOI: 10.4172/21577439.1000164 .

[28] Zhang, Z.; Mei, L.; Feng, S.-S. Paclitaxel Drug Delivery Systems. Expert Opin. Drug Deliv. 2013, 10 (3), 325-340. DOI: 10.1517/ 17425247.2013.752354. 
[29] Yang, T.; Cui, F. De; Choi, M. K.; Cho, J. W.; Chung, S. J.; Shim, C. K.; Kim, D. D. Enhanced Solubility and Stability of PEGylated Liposomal Paclitaxel: In Vitro and in Vivo Evaluation. Int. J. Pharm. 2007, 338 (1-2), 317-326. DOI: 10.1016/j.ijpharm.2007.02.011.

[30] Jin, C.; Bai, L.; Wu, H.; Song, W.; Guo, G.; Dou, K. Cytotoxicity of Paclitaxel Incorporated in Plga Nanoparticles on Hypoxic Human Tumor Cells. Pharm. Res. 2009, 26 (7), 1776-1784. DOI: 10.1007/ s11095-009-9889-z.

[31] Eloy, J. O.; Petrilli, R.; Chesca, D. L.; Saggioro, F. P.; Lee, R. J.; Marchetti, J. M. Anti-HER2 Immunoliposomes for Co-Delivery of Paclitaxel and Rapamycin for Breast Cancer Therapy. Eur. J. Pharm. Biopharm. 2017, 115, 159-167. DOI: 10.1016/j.ejpb.2017.02.020.

[32] Teow, H. M.; Zhou, Z.; Najlah, M.; Yusof, S. R.; Abbott, N. J.; D’Emanuele, A. Delivery of Paclitaxel Across Cellular Barriers Using a Dendrimer-Based Nanocarrier. Int. J. Pharm. 2013, 441 (1-2), 701-711. DOI: 10.1016/j.ijpharm.2012.10.024.

[33] Emami, J.; Rezazadeh, M.; Hasanzadeh, F.; Sadeghi, H.; Mostafavi, A.; Minaiyan, M.; Rostami, M.; Davies, N. Development and In Vitro/In Vivo Evaluation of a Novel Targeted Polymeric Micelle for Delivery of Paclitaxel. Int. J. Biol. Macromol. 2015, 80, 29-40. DOI: 10.1016/j. ijbiomac.2015.05.062.

[34] Sahoo, S. K.; Ma, W.; Labhasetwar, V. Efficacy of Transferrin-Conjugated Paclitaxel-Loaded Nanoparticles in a Murine Model of Prostate Cancer. Int. J. Cancer 2004, 112 (2), 335-340. DOI: 10.1002/ijc.20405.

[35] Hawkins, M. J.; Soon-Shiong, P.; Desai, N. Protein Nanoparticles as Drug Carriers in Clinical Medicine. Adv. Drug Deliv. Rev. 2008, 60 (8), 876-885. DOI: 10.1016/j.addr.2007.08.044.

[36] Green, M. R.; Manikhas, G. M.; Orlov, S.; Afanasyev, B.; Makhson, A. M.; Bhar, P.; Hawkins, M. J. Abraxane ${ }^{\circledR}$, a Novel Cremophor ${ }^{\circledR}$-free, Albumin-Bound Particle Form of Paclitaxel for the Treatment of Advanced Non-Small-Cell Lung Cancer. Ann. Oncol. 2006, 17 (8), 1263-1268. DOI: 10.1093/annonc/mdl104.

[37] Uslu, B.; Lingeman, H.; Ozkan, S. A.; Palit, M.; Dogan-Topal, B. Analytical Method Development and Validation of Pharmaceutical Analysis Using Chromatographic Techniques. Chromatogr. Res. Int. 2012, 2012, 1. DOI: $10.1155 / 2012 / 948129$.

[38] Siddiqui, M. R.; AlOthman, Z. A.; Rahman, N. Analytical Techniques in Pharmaceutical Analysis: A Review. Arab. J. Chem. 2017, 10 (April), S1409-S1421. DOI: 10.1016/j.arabjc.2013.04.016.

[39] United States Pharmacopeia Convention. The United States Pharmacopeia, The National Formulary. USP 29nd rev. NF, 24th ed.; The Convention: Rockville (MD), 2009; Vol. 2, Available at: http://www. pharmacopeia.cn/v29240/usp29nf24s0_m60190.html (accessed Nov $5,2017)$.

[40] Svojanovsky, S. R.; Egodage, K. L.; Wu, J.; Slavik, M.; Wilson, G. S. High Sensitivity ELISA Determination of Taxol in Various Human Biological Fluids. J. Pharm. Biomed. Anal. 1999, 20 (3), 549-555. DOI: 10.1016/S0731-7085(99)00073-4.

[41] Bicamumpaka, C.; Pag, M. IMMWOW6ICAL Development of a Fluorescence Polarization Immunoassay for the Quantitative Determination of Paclitaxel. J. Immunol. Methods. 1998, 12, 1-7. DOI: 10.1016/S0022-1759(97)00183-X.

[42] Guillemard, V.; Bicamumpaka, C.; Boucher, N.; Pagé, M. Development of a Very Sensitive Luminescence Assay for the Measurement of Paclitaxel and Related Taxanes. Anticancer Res. 1999, 19 (6B), 5127-5130. PMID: 10697521.

[43] Hamel, E.; Lin, C. M.; Johns, D. G. Tubulin-Dependent Biochemical Assay for the Antineoplastic Agent Taxol and Application to Measurement of the Drug in Serum. Cancer Treat. Rep. 1982, 66 (6), 13811386. PMID: 6123384.

[44] Sheikh, S. H.; Mulchandani, A. Continuous-Flow Fluoro-Immunosensor for Paclitaxel Measurement. Biosens. Bioelectron. 2001, 16 (912), 647-652. DOI: 10.1016/S0956-5663(01)00193-2.

[45] Darwish, I. A. Immunoassay Methods and Their Applications in Pharmaceutical Analysis: Basic Methodology and Recent Advances. Int. J. Biomed. Sciense 2006, 2 (2), 217-235. PMID: 23674985. PMCID: PMC3614608.

[46] Morais, S.; O’Malley, S.; Chen, W.; Mulchandani, A. A TubulinBased Fluorescent Polarization Assay for Paclitaxel. Anal. Biochem. 2003, 321 (1), 44-49. DOI: 10.1016/S0003-2697(03)00436-6.
[47] Hempel, G.; Lehmkuhl, D.; Krümpelmann, S.; Blaschke, G.; Boos, J. Determination of Paclitaxel in Biological Fluids by Micellar Electrokinetic Chromatography. J. Chromatogr. A 1996, 745 (1-2), 173179. DOI: 10.1016/0021-9673(96)00351-2.

[48] Rodríguez, J.; Castañeda, G.; Contento, A. M.; Muñoz, L. Direct and Fast Determination of Paclitaxel, Morphine and Codeine In Urine By Micellar Electrokinetic Chromatography. J. Chromatogr. A 2012, 1231, 66-72. DOI: 10.1016/j.chroma.2012.02.003.

[49] Chan, K. C.; Belinda Alvarado, A.; McGuire, M. T.; Muschik, G. M.; Issaq, H. J.; Snader, K. M. High-Performance Liquid Chromatography and Micellar Electrokinetic Chromatography of Taxol and Related Taxanes From Bark and Needle Extracts of Taxus Species. J. Chromatogr. B Biomed. Sci. Appl. 1994, 657 (2), 301-306. DOI 10.1016/S0378-4347(94)80006-5.

[50] Rodríguez, J.; Contento, A. M.; Castañeda, G.; Muñoz, L.; Berciano, M. A. Determination of Morphine, Codeine, and Paclitaxel In Human Serum and Plasma By Micellar Electrokinetic Chromatography. J. Sep. Sci. 2012, 35 (17), 2297-2306. DOI: 10.1002/ jssc. 201200375 .

[51] Thormann, W.; Lienhard, S.; Wernly, P. Strategies for the Monitoring of Drugs in Body Fluids by Micellar Electrokinetic Capillary Chromatography. J. Chromatogr. 1993, 636 (1), 137-148. DOI 10.1016/0021-9673(93)80066-H.

[52] Barbosa, M. V.; Monteiro, L. O. F.; Malagutti, A. R.; Oliveira, M. C.; Carvalho-Junior, A. D.; Leite, E. A. Comparative Study of FirstDerivative Spectrophotometry and High Performance Liquid Chromatography Methods for Quantification of Paclitaxel in Liposomal Formulation. J. Braz. Chem. Soc. 2015, 26 (7), 1338-1343. DOI: 10.5935/0103-5053.20150100.

[53] Hendrikx, J. J. M. A.; Hillebrand, M. J. X.; Thijssen, B.; Rosing, H.; Schinkel, A. H.; Schellens, J. H. M.; Beijnen, J. H. A Sensitive Combined Assay for the Quantification of Paclitaxel, Docetaxel and Ritonavir in Human Plasma Using Liquid Chromatography Coupled with Tandem Mass Spectrometry. J. Chromatogr. B. Analyt. Technol. Biomed. Life Sci. 2011, 879 (28), 2984-2990. DOI: 10.1016/j. jchromb.2011.08.034.

[54] Tian, J.; Stella, V. J. Degradation of Paclitaxel and Related Compounds in Aqueous Solutions III: Degradation Under Acidic PH Conditions and Overall Kinetics. J. Pharm. Sci. 2010, 99 (3), 12881298. DOI: $10.1002 / j p s .21910$.

[55] Tian, J.; Stella, V. J. Degradation of Paclitaxel and Related Compounds in Aqueous Solutions II: Nonepimerization Degradation Under Neutral to Basic PH Conditions. J. Pharm. Sci. 2008, 97 (8), 3100-3108. DOI: 10.1002/jps.21214.

[56] Tian, J.; Stella, V. J. Degradation of Paclitaxel and Related Compounds in Aqueous Solutions I: EPIMERIZATION. J. Pharm. Sci. 2008, 97 (3), 1224-1235. DOI: 10.1002/jps.21112.

[57] Snyder, L. R.; Kirkland, J. J.; Dolan, J. W. Introduction to Modern Liquid Chromatography; John Wiley \& Sons, Inc.: Hoboken, NJ, USA, 2009.

[58] Tong, X.; Zhou, J.; Tan, Y. Liquid Chromatography/Tandem TripleQuadrupole Mass Spectrometry for Determination of Paclitaxel in Rat Tissues. Rapid Commun. Mass Spectrom. 2006, 20 (12), 19051912. DOI: $10.1002 / \mathrm{rcm} .2525$.

[59] Tong, X.; Zhou, J.; Tan, Y. Determination of Paclitaxel in Rat Plasma by LC-MS-MS. J. Chromatogr. Sci. 2006, 44 (5), 266-271. PMID 16774712 .

[60] Li, P.; Albrecht, B. J.; Yan, X.; Gao, M.; Weng, H. R.; Bartlett, M. G. A rapid Analytical Method for the Quantification of Paclitaxel in Rat Plasma and Brain Tissue by High-Performance Liquid Chromatography and Tandem Mass Spectrometry. Rapid Commun. Mass Spectrom. 2013, 27 (19), 2127-2134. DOI: 10.1002/rcm.6671.

[61] Yonemoto, H.; Ogino, S.; Nakashima, M. N.; Wada, M.; Nakashima, K. Determination of Paclitaxel in Human and Rat Blood Samples After Administration of Low Dose Paclitaxel by HPLC-UV Detection. Biomed. Chromatogr. 2007, 21 (3), 310-317. DOI: 10.1002/bmc.759.

[62] Andersen, A.; Warren, D. J.; Brunsvig, P. F.; Aamdal, S.; Kristensen, G. B.; Olsen, H. High Sensitivity Assays for Docetaxel and Paclitaxel in Plasma Using Solid-Phase Extraction and High-Performance Liquid Chromatography with UV Detection. BMC Clin. Pharmacol. 2006, 6, 2. DOI: 10.1186/1472-6904-6-2. 
[63] Gaspar, J. R.; Qu, J.; Straubinger, N. L.; Straubinger, R. M. Highly Selective and Sensitive Assay For Paclitaxel Accumulation By Tumor Cells Based on Selective Solid Phase Extraction and Micro-Flow Liquid Chromatography Coupled to Mass Spectrometry. Analyst 2008, 133 (12), 1742-1748. DOI: 10.1039/b806856a.

[64] Alexander, M. S.; Kiser, M. M.; Culley, T.; Kern, J. R.; Dolan, J. W.; McChesney, J. D.; Zygmunt, J.; Bannister, S. J. Measurement of Paclitaxel in Biological Matrices: High-Throughput Liquid Chromatographic-Tandem Mass Spectrometric Quantification of Paclitaxel and Metabolites in Human and Dog Plasma. J. Chromatogr. B Anal. Technol. Biomed. Life Sci. 2003, 785 (2), 253-261. DOI: 10.1016/S1570-0232(02)00913-3.

[65] Guo, W.; Johnson, J. L.; Khan, S.; Ahmad, A.; Ahmad, I. Paclitaxel Quantification in Mouse Plasma and Tissues Containing LiposomeEntrapped Paclitaxel By Liquid Chromatography-Tandem Mass Spectrometry: Application to a Pharmacokinetics Study. Anal. Biochem. 2005, 336 (2), 213-220. DOI: 10.1016/j.ab.2004.09.046.

[66] Gao, Y.; Chen, J.; Zhang, X.; Xie, H.; Wang, Y.; Guo, S. Quantification of Paclitaxel and Polyaspartate Paclitaxel Conjugate in Beagle Plasma: Application to a Pharmacokinetic Study. J. Chromatogr. Sci. 2017, 55 (3), 222-231. DOI: 10.1093/chromsci/bmw174.

[67] Parise, R. A.; Ramanathan, R. K.; Zamboni, W. C.; Egorin, M. J. Sensitive Liquid Chromatography-Mass Spectrometry Assay for Quantitation of Docetaxel and Paclitaxel in Human Plasma. J. Chromatogr. B Anal. Technol. Biomed. Life Sci. 2003, 783 (1), 231-236. DOI: 10.1016/S1570-0232(02)00659-1.

[68] Gréen, H.; Vretenbrant, K.; Norlander, B.; Peterson, C. Measurement of Paclitaxel and Its Metabolites in Human Plasma Using Liquid Chromatography/Ion Trap Mass Spectrometry with a Sonic Spray Ionization Interface. Rapid Commun. Mass Spectrom. 2006, 20 (14), 2183-2189. DOI: $10.1002 / \mathrm{rcm} .2567$.

[69] Zhang, W.; Dutschman, G. E.; Li, X.; Cheng, Y.-C. Quantitation of Paclitaxel and Its Two Major Metabolites Using a Liquid Chromatography-Electrospray Ionization Tandem Mass Spectrometry. J. Chromatogr. $B$ 2011, 879 (22), 2018-2022. DOI: 10.1016/j. jchromb.2011.05.024.

[70] Zhang, S. Q.; Song, Y. N.; He, X. H.; Zhong, B. H.; Zhang, Z. Q. Liquid chromatography-Tandem Mass Spectrometry for the Determination of Paclitaxel in Rat Plasma After Intravenous Administration of Poly(lglutamic acid)-Alanine-Paclitaxel Conjugate. J. Pharm. Biomed. Anal. 2010, 51 (5), 1169-1174. DOI: 10.1016/j.jpba.2009.11.030.

[71] Zhang, S.-Q.; Chen, G.-H. Determination of Paclitaxel in Human Plasma by UPLC-MS-MS. J. Chromatogr. Sci. 2008, 46 (3), 220-224. DOI: $10.1211 / 146080899128734172$.

[72] Yu, H.; Straubinger, R. M.; Cao, J.; Wang, H.; Qu, J. Ultra-Sensitive Quantification of Paclitaxel Using Selective Solid-Phase Extraction in Conjunction With Reversed-Phase Capillary Liquid Chromatography/Tandem Mass Spectrometry. J. Chromatogr. A 2008, 1210 (2), 160-167. DOI: 10.1016/j.chroma.2008.09.052.

[73] Stokvis, E.; Ouwehand, M.; Nan, L. G. A. H.; Kemper, E. M.; Van Tellingen, O.; Rosing, H.; Beijnen, J. H. A Simple and Sensitive Assay for the Quantitative Analysis of Paclitaxel in Human and Mouse Plasma and Brain Tumor Tissue Using Coupled Liquid Chromatography and Tandem Mass Spectrometry. J. Mass Spectrom. 2004, 39 (12), 1506-1512. DOI: $10.1002 /$ jms.747.

[74] Sottani, C.; Minoia, C.; D’Incalci, M.; Paganini, M.; Zucchetti, M. High-Performance Liquid Chromatography Tandem Mass Spectrometry Procedure with Automated Solid Phase Extraction Sample Preparation for the Quantitative Determination of Paclitaxel (Taxol) In Human Plasma. Rapid Commun. Mass Spectrom. 1998, 12 (5), 251-255. DOI: 10.1002/(SICI)1097-0231(19980314)12:5<251::AIDRCM145>3.0.CO;2-Z.

[75] Paek, I. B.; Ji, H. Y.; Kim, M. S.; Lee, G. S.; Lee, H. S. Simultaneous Determination of Paclitaxel and a New P-Glycoprotein Inhibitor HM-30181 in Rat Plasma By Liquid Chromatography With Tandem Mass Spectrometry. J. Sep. Sci. 2006, 29 (5), 628-634. DOI: 10.1002/ jssc. 200500368 .

[76] Mortier, K. A; Renard, V.; Verstraete, A. G.; Lambert, W. E.; Gussem, A. Van; Belle, S. Van. Development and Validation of a Liquid Chromatography-Tandem Mass Spectrometry Assay for the
Quantification of Docetaxel and Paclitaxel in Human Plasma and Oral Fluid. Anal. Chem. 2005, 77 (14), 4677-4683. DOI: 10.1021/ ac0500941.

[77] Guo, P.; Ma, J.; Li, S.; Gallo, J. Determination of Paclitaxel In Mouse Plasma and Brain Tissue By Liquid Chromatography-Mass Spectrometry. J. Chromatogr. B 2003, 798 (1), 79-86. DOI: 10.1016/j. jchromb.2003.08.049.

[78] Basileo, G.; Breda, M.; Fonte, G.; Pisano, R.; James, C. A. Quantitative Determination of Paclitaxel in Human Plasma Using Semi-Automated Liquid-Liquid Extraction in Conjunction with Liquid Chromatography/Tandem Mass Spectrometry. J. Pharm. Biomed. Anal. 2003, 32 (4-5), 591-600. DOI: 10.1016/S0731-7085(03)00166-3.

[79] Nageswara Rao, R.; Satyanarayana Raju, S.; Mastan Vali, R.; Sarma V. U. M.; Girija Sankar, G. LC-ESI-MS/MS Determination of Paclitaxel on Dried Blood Spots. Biomed. Chromatogr. 2012, 26 (5), 616621. DOI: 10.1002/bmc.1706.

[80] Li, S.; Fu, Y.; Zu, Y.; Sun, R.; Wang, Y.; Zhang, L.; Luo, H.; Gu, C.; Efferth, T. Determination of Paclitaxel and Other Six Taxoids In Taxus Species By High-Performance Liquid ChromatographyTandem Mass Spectrometry. J. Pharm. Biomed. Anal. 2009, 49 (1), 81-89. DOI: 10.1016/j.jpba.2008.10.006.

[81] Shao, L. K.; Locke, D. C. Determination of Paclitaxel and Related Taxanes in Bulk Drug and Injectable Dosage Forms by Reversed Phase Liquid Chromatography. Anal. Chem. 1997, 69 (11), 20082016. DOI: $10.1021 / \mathrm{ac} 961312 \mathrm{~g}$.

[82] Grobosch, T.; Schwarze, B.; Stoecklein, D.; Binscheck, T. Fatal Poisoning with Taxus Baccata. Quantification of Paclitaxel (taxol A), 10-deacetyltaxol, Baccatin III, 10-Deacetylbaccatin III, Cephalomannine (taxol B), and 3,5-Dimethoxyphenol in Body Fluids by Liquid Chromatography-Tandem Mass Spectrometry. J. Anal. Toxicol. 2012, 36 (1), 36-43. DOI: 10.1093/jat/bkr012.

[83] Xavier Junior, F. H.; Gueutin, C.; do Vale Morais, A. R.; do Nascimento Alencar, E.; do Egito, E. S. T.; Vauthier, C. HPLC Method for the Dosage of Paclitaxel in Copaiba Oil: Development, Validation, Application to the Determination of the Solubility and Partition Coefficients. Chromatographia 2016, 79 (7-8), 405-412. DOI: 10.1007/s10337-016-3058-4.

[84] Talebi, M.; Ghassempour, A.; Talebpour, Z.; Rassouli, A.; Dolatyari, L. Optimization of the Extraction of Paclitaxel from Taxus Baccata L. by the Use of Microwave Energy. J. Sep. Sci. 2004, 27 (13), 11301136. DOI: 10.1002/jssc.200401754.

[85] Mittal, A.; Chitkara, D.; Kumar, N. HPLC Method for the Determination of Carboplatin and Paclitaxel with Cremophorel in an Amphiphilic Polymer Matrix. J. Chromatogr. B Anal. Technol. Biomed. Life Sci. 2007, 855 (2 SPEC. ISS.), 211-219. DOI: 10.1016/j. jchromb.2007.05.005.

[86] Ciutaru, D.; Badea, I.; Lazar, L.; Nicolescu, D.; Tudose, A. A HPLC Validated Assay of Paclitaxel's Related Impurities in Pharmaceutical Forms Containing Cremophor? EL. J. Pharm. Biomed. Anal. 2004, 34 (3), 493-499. DOI: 10.1016/S0731-7085(03)00632-0.

[87] Turner, E. A.; Stenson, A. C.; Yazdani, S. K. HPLC-MS/MS Method for Quantification of Paclitaxel from Keratin Containing Samples. J. Pharm. Biomed. Anal. 2017, 139, 247-251. DOI: 10.1016/j. jpba.2017.03.011.

[88] Eloy, J. O.; Petrilli, R.; Topan, J. F.; Antonio, H. M. R.; Barcellos, J. P. A.; Chesca, D. L.; Serafini, L. N.; Tiezzi, D. G.; Lee, R. J.; Marchetti, J. M. Co-Loaded Paclitaxel/Rapamycin Liposomes: Development, Characterization and In Vitro and In Vivo Evaluation for Breast Cancer Therapy. Colloids Surfaces B Biointerfaces 2016, 141, 74-82. DOI: 10.1016/j.colsurfb.2016.01.032.

[89] Yang, T.; Choi, M. K.; Cui, F. De; Kim, J. S.; Chung, S. J.; Shim, C. K.; Kim, D. D. Preparation and Evaluation of Paclitaxel-Loaded PEGylated Immunoliposome. J. Control. Release 2007, 120 (3), 169-177. DOI: 10.1016/j.jconrel.2007.05.011.

[90] Le Broc-Ryckewaert, D.; Carpentier, R.; Lipka, E.; Daher, S.; Vaccher, C.; Betbeder, D.; Furman, C. Development of Innovative PaclitaxelLoaded Small PLGA Nanoparticles: Study of Their Antiproliferative Activity and Their Molecular Interactions on Prostatic Cancer Cells Int. J. Pharm. 2013, 454 (2), 712-719. DOI: 10.1016/j. ijpharm.2013.05.018. 